\title{
Piercing of the Corporate Veil in Korea: Case Commentary
}

\author{
Eun Young Shin* and In Yeung J. Cho**
}

\begin{abstract}
The purpose of this Commentary is to critically appraise the jurisprudence of Korea on the doctrine of corporate veil piercing with a special emphasis on the Korean Supreme Court's decision in 2004Da26119. In 2004Da26119, the Supreme Court of Korea delineated the criteria for disregarding the corporate entity under Korean corporate law, particularly in the parentsubsidiary context. As part of its purported aim, the Commentary will analyze the constitutive elements of veil piercing as understood by Korean courts and attempt to survey the evolution of jurisprudence on veil piercing leading up to 2004Da26119. The Commentary will argue that a showing of parental motive and/or purpose, which the Supreme Court required in 2004Da26119 as part of prima facie proof for veil piercing, may well dampen the overall efficacy of veil piercing in Korea, due to the evidentiary hardship it will pose in practice.
\end{abstract}

\section{Introduction}

Today's corporations set up subsidiaries for a variety of reasons including optimal corporate governance and diversification of business. In the context of a parent-subsidiary relationship, there may be situations where, from a legal

* Eun Young Shin, Esq. is an associate at Lee \& Ko and a member of the Korean Bar Association (email: eys@leeko.com). She received an LL.B. in 1999 from Seoul National University, and an LL.M. in 2001 from Graduate School of Law, Seoul National University. Ms. Shin's areas of practice include corporate governance and M\&A.

** In Yeung J. Cho, Esq. is General Counsel at Samsung Thales Co., Ltd. (email: inyeungj_cho@yahoo.com). He received a B.A. in 1997 from the University of Toronto, an LL.B. in 2000 from Osgoode Hall Law School of York University, and an LL.M. in 2006 from the University of London; was Legal Counsel to the Ministry of Foreign Affairs and Trade in Seoul, Korea (2003-2004); and a Visiting Scholar, the University of British Columbia Faculty of Law (2006).

The authors wish to extend genuine gratitude to Mr. Hyeong Gun Lee, Esq., a partner at Lee \& Ko, for his insightful comments on an earlier draft. The views and opinions expressed herein are solely those of the authors. 
standpoint, each constituent company exists as a separate entity, whereas, from an economic viewpoint, the subsidiary in effect operates under uniform control of the parent. In situations involving such a corporate group, treating the parent company and its subsidiary as distinct legal entities may result in an outcome that, depending on the facts involved, defies the principle of justice and equity. The utility of piercing the corporate veil ${ }^{1}$ has been debated in Korea in an ongoing bid to redress such possible inequity. Arguably, while the concept of veil piercing $\left.{ }^{2}\right)$ is not confined to the realm of parent companysubsidiaries, cases involving a single economic unit would, in general, be more prone to veil piercing than others. In fact, the doctrine of veil piercing is likely to foment more issues and controversies in the parent-subsidiary context than any other.

In the case at hand, ${ }^{3)}$ the plaintiff put forward the allegation that the defendant's denial of liability behind the façade of a subsidiary controlled by him, amounted to an abuse of corporate personality in contravention to the principle of good faith, ${ }^{4)}$ but the Supreme Court of Korea held that the facts of the case did not warrant the corporate veil to be lifted. In so holding, the Court spelled out the criteria for disregarding the corporate entity under Korean corporate law.

In what follows, we will first examine the existing case laws in Korea on veil piercing followed by an appraisal of 2004Da26119 from the perspective of bringing veil piercing into play in the parent company-subsidiary context.

1) See Black's Law Dictionary 1168 ( $7^{\text {th }}$ ed. 1999) (defining "piercing the corporate veil: the judicial act of imposing liability on otherwise immune corporate officers, directors, and shareholders for the corporation's wrongful acts. Also termed disregarding the corporate entity.").

2) In Korea, the term "Beop-in-kyuk-bu-in" (disregarding the corporate entity) is used to describe this judicial action.

3) Judgment of Aug. 25, 2006, 2004 Da26119 (Supreme Court of Korea) [hereinafter 2004Da26119].

4) In 2004Da26119, the plaintiff also alleged the presence of a guaranty and of an intent to create an agency at the end of the defendant, ratification of acts of an agent with no authority, issuance of work direction in violation of Article 401(2) of the SANGBEOP [KOREAN COMMERCIAL CODE], and establishment of joint torts as the grounds of appeal, and the Supreme Court ruled thereon. Such rulings, however, are beyond the scope of this Commentary. 


\title{
II. Existing Case Laws in Korea on Corporate Veil Piercing ${ }^{5)}$
}

\author{
1. Judgment of Sept. 13, 1977, 74Da954 (Supreme Court of Korea)
}

\section{1) Facts of $74 D a 954$}

The facts of this case are as follows. Origin Co., Ltd. ("Origin") was a limited liability company incorporated by defendant Bong-Gil Kim, ${ }^{6}$ ) his wife, brother-in-law, other close relatives, and law clerk on July 10, 1967. The business name of Origin later changed to Taewon Co., Ltd. ("Taewon") as of November 12, 1968. From its inception as Origin, Taewon was incorporated as a shelf company through arbitrary use by the defendant of the names of his wife, next of kin, and law clerk. The defendant appointed himself as the Representative Director of Taewon with virtually all of the working capital personally financed by him. As a consequence, the defendant could readily position himself as the controlling shareholder, and the allotment of shares to the name-only equity holders including his wife, next of kin and law clerk was made at the whim of the defendant in the form of gift or contributory stocks. Also, the capital of $\mathrm{KRW}^{7} 5$ million at the time of incorporation (later increased to KRW 10 million) was relatively small for the volume of overseas exports Taewon was engaging in (amounting to $\$ 10,000$ ). Further, the basic assets of Taewon consisted of only a few parcels of industrial land at Hwa-yong Dong, Sung-dong District in Seoul. On account of its unsound financial conditions, Taewon evidently relied on outside credit facilities for management purposes including those from the plaintiff.

In addition, the business office of Taewon was located inside the defendant's law office, and the company was effectively run as the defendant's privately owned business with the requisite legal formalities either kept to a bare minimum or ignored outright. Further, the assets of Taewon and the defendant's personal assets were improperly mixed. As such, when there was a pressing

5) It is noted that there is no express statutory basis in Korea for corporate veil piercing. Pertinent case laws seem to have based veil piercing on the principle of good faith as codified in the MinBeop [Civil CODE] (Korean); see infra note 9.

6) Bong-Gil Kim was an attorney-at-law by profession.

7) Refers to Korean Won, the official currency of the Republic of Korea. 
need to settle the accounts of Taewon, the defendant's personal assets were used towards that end, and as the liabilities of Taewon mounted resulting in increased risk of attachment against certain assets of the company, the defendant effected the provisional registration of such assets under his name and subsequently disposed of the same, thereby siphoning off corporate assets and leaving creditors with little or no recourse.

As the company drifted further into doldrums, the defendant ran Taewon like a sole proprietorship by turning a blind eye to corporate formalities including those on shareholders meetings, board of directors' resolutions, and invocation of right to auditing. In effect, Taewon was nothing but a sham sugarcoated with the appearance of a limited liability corporation.

In the meanwhile, Taewon issued several promissory notes to the plaintiff from June 3, 1969 to August 26, 1969 for a total of KRW 8,240,000. When these promissory notes were not honored as they became due, the plaintiff instituted an in personam proceeding against the defendant to enforce its creditor rights.

\section{2) Judicial holdings of $74 \mathrm{Da} 954$ and comments}

At the appellate level, the Seoul High Court affirmed abuse by the defendant of the corporate personality of Taewon from the facts that: i) the defendant used Taewon as a façade; ii) the company was in effect operated as the defendant's personal enterprise; iii) Taewon was undercapitalized; iv) the defendant ignored corporate formalities and protocols; and v) the defendant siphoned off corporate assets for the purpose of preempting creditor claims and enforcement actions against Taewon. ${ }^{8)}$ The court held that the foregoing acts of abuse would not only render the very purpose of corporate entity, a legal fiction concocted to acclimate societal and economic impacts of the corporation, meaningless, but also dispel substantive justice and the principle

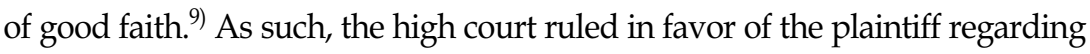
his creditor claims involving the liabilities of Taewon. ${ }^{10}$

8) Judgment of May 8, 1974, 72Na2582 (Seoul High Ct.).

9) Id. The principle of good faith is codified in Article 2(1) of the CIVIL CODE, which provides: "The exercise of rights and the performance of duties shall be in accordance with the principle of trust and good faith."

10) $I d$. 
Subsequently, the Supreme Court overturned the high court judgment with a brief ratio that the company was not a mere façade and did not further articulate on the contours of veil piercing that had been adopted in the affirmative at the appellate level. ${ }^{11)}$

In respect of the Supreme Court ruling, legal commentators critiqued the Court as having erred in refusing to lift the corporate veil for the reason that Taewon was a legitimate one man company, for such refusal stemmed from a mischaracterization of veil piercing. ${ }^{12)}$

\section{Judgment of Nov. 22, 1988, 87Daka1671 (Supreme Court of Korea)}

\section{1) Facts of 87Daka1671}

The facts of this decision are as follows. Defendants Hyundai Mipo Dockyard ("HMD") and Samsung Aerial Services provisionally attached a commercial vessel (the "Subject Vessel") to preserve the enforcement of their individual monetary claims against Chipstead Co., Ltd ("Chipstead"). Plaintiff Grand Harmony Inc., the owner of the Subject Vessel, commenced a third party action challenging the validity of the provisional attachment. Chipstead was not privy to the suit.

The plaintiff was a Liberian company with its main offices at 80 Monrovia Broad Street. ${ }^{13)}$ On April 1, 1981, the plaintiff and Touchest Shipping Ltd., a Liberian company with the same main office as plaintiff ("Touchest"), entered into a maintenance contract in respect of the Subject Vessel. ${ }^{14)}$ The signatories to this contract were Daniel Puchieh Lee on behalf of the plaintiff and Denis Puping Lee on behalf of Touchest, respectively. ${ }^{15)}$ On the same day, Touchest signed off a sub-agency contract with Chipstead whose main office was at Kennedy Road, Hong Kong, for maintenance of the Subject Vessel. The signatories to this sub-agency contract were Denis Puping Lee on behalf of Touchest and Daniel Puchieh Lee on behalf of Chipstead, respectively. ${ }^{16)}$

11) $74 \mathrm{Da} 954$.

12) Jae-Hyeong Chang, Panryeeh natanan beopinkyeokbuin [The Doctrine of Corporate Veil Piercing in Case Law], 15-1 Seoul Bar Association Case Law Study 147, 154 (2001).

13) 87 Daka1671, at 64 .

14) Id.

15) Id.

16) $I d$. 
The de facto address of Touchest was identical to that of Chipstead, and they shared phone and facsimile numbers. ${ }^{17}$ ) The chairman of Touchest was Dennis Puping Lee, who served as the president of the plaintiff company, and Touchest's president was Daniel Puchieh Lee, who was also the executive director of the plaintiff. ${ }^{18)}$ The directors of Chipstead consisted of Daniel Puchieh Lee and Denis Puping Lee, who were siblings. ${ }^{19)}$ Upon a direction to get the Subject Vessel fixed at HMD, the vessel was arranged to enter the port of Ulsan on April 1, 1985; at the time of the entry, Chipstead Hong Kong was recorded in as the owner of the vessel. ${ }^{20)}$ Later, when Suk-Lock Lee, who served as Head of the Tokyo Branch of Chipstead, signed off a service contract with HMD on June 10, 1985 in consideration of repair services to be dispensed by HMD, Mr. Lee put Chipstead on the contract as the vessel owner. ${ }^{21)}$ As such, HMD undertook repairs with the knowledge that the Subject Vessel legitimately belonged to Chipstead. ${ }^{22}$ )

The Court also noted that it is customary in the international shipping industry for a ship owner to set up a shelf company in such places as Panama or Liberia, as opposed to the country of the owner's nationality or of the corporate origin, register the ship under the name of such shelf company, hoist the flag of the country of registry, and so sail. ${ }^{23}$ Following or concurrently with the registration process, the actual owner enters into a maintenance contract with the shelf company and purports to merely act as a managing corporation. ${ }^{24)}$ This practice enables ship owners to perform jurisdiction shopping and benefit from variances in finance, labor and regulatory regime between the owner's country of origin and the country of registry, for ease and maximal efficacy in management. ${ }^{25)}$ In light of this trade practice, it is customary for dockyards and related businesses to sign off contractual arrangements with the managing corporation who is the actual owner of the

17) Id. at 65.

18) Id.

19) $I d$.

20) Id.

21) $I d$.

22) $I d$.

23) $I d$.

24) Id.

25) Id. at 65-66. 
ship, as opposed to the registered owner, and get remunerated as such. ${ }^{26)}$

\section{2) Judicial rulings of 87Daka1671}

Affirming the appellate court ruling, the Supreme Court noted that even though Touchest and Chipstead were disparate entities outwardly, Chipstead had in fact incorporated the plaintiff and Touchest, both of which shared the same corporate office and management, for managerial convenience. ${ }^{27)}$ In view of this finding, the Court denied the plaintiff its plea alleging the distinct legal entity of Touchest and Chipstead, as such claim was aimed at avoidance of obligations and hence counter to the principle of good faith. ${ }^{28)}$

The majority of Korean jurists touted this judgment as squarely affirming the principle of veil piercing. ${ }^{29)}$ The decision, however, was subject to criticism as it merely adumbrated the principle without defining its four corners. ${ }^{30)}$ That is, some scholars suggested that the Court in 87 Daka1671 had failed to ascertain a sufficient factual basis for finding an abuse of the corporate entity, other than the sharing of the same office and management as between Touchest and Chipstead. ${ }^{31)}$ Other jurists suggest that 87 Daka1671 was not a case about veil piercing per se, but an attempt at analogizing veil piercing with violation of the principle of good faith and trust. ${ }^{32}$ Accordingly, there is a lingering doubt as to whether 87Daka1671 embodies a landmark decision

26) $I d$. at 66 .

27) $I d$.

28) $I d$.

29) Although the facts of 87 Daka1671 do not fit the mould of the typical veil piercing case, in which liability is usually sought against the company's shareholders or officers, the Court appears to have affirmed veil piercing in this case following the enterprise liability doctrine developed in the U.S. Under this doctrine, U.S. courts sometimes disregard "multiple incorporations of the same business under common ownership," especially where a business is divided into several affiliate or sister entities owned by the same investor(s). See Alan R. Palmiter Corporations 556 ( $5^{\text {th }}$ ed. 2006). For the representative case under the doctrine, see Walkovsky v. Carlton, 223 N.E. 2d 6 (N.Y. 1966). Since, as surveyed above, $87 D a k a 1671$ involved multiple incorporations (i.e. Touchest and Chipstead) under common ownership, it might have proved an apt occasion for the Court to adopt the enterprise liability doctrine in the affirmative.

30) See, e.g., Chan-Hyung Jung, Beopinkyeok buinron [Doctrine of Corporate Veil Piercing], 226 Case Law Monthly 29, 35-36 (Jul. 1989).

31) See, Dong-yun Chung, Beopinkyeok buinroneh kwanhan daebeopwonpanryeui chueui [Trend of Supreme Court Cases on Veil Piercing] 20 LAWYER (Jan. 1990).

32) Jung, supra note 30 , at 35-6. 
affirming veil piercing for the first time at the Court level. 87Daka1671 is nevertheless meaningful in that it served as the judicial vehicle for igniting scholarly debates in Korea on the contours of veil piercing.

\section{Judgment of Jan. 19, 2001, 97Da21604 (Supreme Court of Korea)}

\section{1) Facts of $97 \mathrm{Da} 21604$}

The facts of this decision are as follows. Defendant Samjin Co., Ltd. ("Samjin") whose Representative Director was Jung-Su Lee who was also a codefendant in the case, was in the business of selling units of a commercial high-rise (a seventeen-story building with a five-story basement) to be constructed by Kunyoung Co., Ltd. ("Kunyoung"). On June 19, 1991, the plaintiff entered into a sale and purchase contract with Samjin for the purchase of a unit (Unit No. 502) of the high-rise. ${ }^{33)}$ Thereafter, the plaintiff made a down payment and two interim payments up until March 30, 1992. ${ }^{34)}$ Samjin's original plan was to finance the high-rise project with the sale proceeds. Yet as Samjin's sale of the high-rise went sour, payments to Kunyoung were delayed, and Kunyoung eventually halted construction as of August, 1992. ${ }^{35)}$

In the meanwhile, defendant Jung-Su Lee was carrying on the business of selling commercial premises and offices in his own name or under the names of entities over which he exerted de facto control. ${ }^{36)}$ As part of this business, Mr. Lee purchased the shares of Samjin on May 3, 1991 from the company's then Representative Director Il-Hyoung Choi and became thereby Samjin's new Representative Director. ${ }^{37)}$

The number of Samjin's issued shares was five thousand which, for recordkeeping purposes, was divided among four equity holders including Jung-Su Lee (Jung-Su Lee owned two thousands of these shares with the rest equally divvied up among the remaining shareholders who were all related to Lee). ${ }^{38)}$ In fact, however, the vast majority of Samjin's issued shares were in the

\footnotetext{
33) $97 \mathrm{Da} 21604$, at 485 .

34) Id.

35) Id. at 486 .

36) Id. at 487.

37) Id.

38) $I d$.
} 
hands of Jung-Su Lee. ${ }^{39)}$ In addition, Lee practically made all managerial decisions of Samjin without observing corporate formalities. ${ }^{40)}$ By the time plaintiff took its suit against the defendants, the offices of Samjin had been permanently shut down. ${ }^{41)}$

From the sale proceeds of the high-rise amounting to KRW 7.8 billion, defendant Jung-Su Lee used approximately KRW 3 billion to purchase the land for the high-rise in his name and arranged for the levying of provisional registration thereon in the name of a third party and had the same terminated subsequently in anticipation of creditor claims. ${ }^{42)}$ For the remaining proceeds, Jung-Su Lee put them to use for untraceable purposes. ${ }^{43)}$ As evidenced by the foregoing, the corporate assets of Samjin and the personal assets of Jung-Su Lee were improperly intermingled. In addition, despite the large-scale of the highrise project, Samjin was heavily undercapitalized with its capital amounting to a meager KRW 50 million. At the end of the day, Samjin was in effect insolvent. $^{44)}$

\section{2) Rulings of 97Da21604/comments}

The Supreme Court held that the plaintiff would be entitled to demand the sale proceeds back from either Samjin or Jung-Su Lee who wielded de facto control over Samjin behind the corporate veil. ${ }^{45)}$ Specifically in relation to the issue of veil piercing, the Supreme Court enunciated in the following vein.

When a company maintains the public appearance of a corporation, but such appearance is merely a sham and the company, in essence, is reduced down to a private enterprise of the principal behind the corporate veil or to an instrument for staving off legal effects at the helm of the principal, it would be egregious to impute liability arising from what is ostensibly an act of the company to the company alone, and not to the principal, based on the former's separate legal persona. ${ }^{46)}$ Such imputation of liability, if accepted by

39) Id. at 488 .

40) Id.

41) Id.

42) Id.

43) $I d$.

44) $I d$.

45) Id.

46) Id. at 487 . 
courts, would constitute an abuse of corporate personality in violation of the principle of good faith and be singularly contrary to justice and equity. From this analysis, it would be sensible to hold both the company and the principal jointly liable for the corporate act at issue. ${ }^{47)}$

In the case at hand, in view of the relevant facts including the backdrop against which the defendant had acquired the ownership of Samjin, the form and extent of Jung-Su Lee's control over Samjin, the degree of asset intermingling between Jung-Su Lee and the company, the state of Samjin's business operation and usage of the sale proceeds, the size of Samjin's commercial real estate business, and overall status of corporate asset and solvency, it was incontrovertible to the Court that, while Samjin took on the form of a limited liability company, it, in essence, was no more than Jung-Su Lee's sole proprietorship. ${ }^{48)}$ Therefore, even though Samjin became the party who sold the high-rise in this case, it was nothing more than just an external appearance and, in substance, the business of selling the high-rise was conducted by Jung$\mathrm{Su}$ Lee as his private business. ${ }^{49}$ )

In this account, trial records indisputably indicated that Jung-Su Lee was relying on the distinct legal entity of Samjin in denying liability in his personal capacity. Such denial, in the Court's view, would be at loggerheads with the precepts of justice and equity. ${ }^{50)}$

In this case, the Supreme Court typified veil piercing into the following two broad categories: i) abuse of corporate personality (i.e. where the corporation is used by the principal as an arbitrary instrument for escaping legal liability); and ii) formalization of corporate personality (i.e. even with the formalities of a corporation, such form is but a cloak, and the corporation, in effect, amounts to a private business of the principal lurking behind the corporate veil).

The Court further delineated the criteria for the formalization of corporate personality on a showing of de facto governance by shareholders of the company, comingling of assets, lack of separate accounting apparatus, intermingling of business status and corporate transactions, undercapitalization,
47) Id.
48) Id. at 488 .
49) Id.
50) Id. 
and failure to observe corporate protocols mandated by law. ${ }^{51)}$ The decision was lauded as the first case in Korea ushering the concept of veil piercing into an actual case setting. ${ }^{52}$

\section{Judgment of Nov. 12, 2004, 2002Da66892 (Supreme Court of Korea)}

\section{1) Facts of 2002Da66892}

The facts of this case are as follows. The plaintiffs leased portions of a building owned by Angunsa Co., Ltd. ("Angunsa") in Sinsa-Dong, Eunpyung District, Seoul and completed the registration of jeonse-kwon ${ }^{53)}$ on their respective leases. Angunsa went bankrupt shortly thereafter, and the above building was auctioned off to a third party at the request of Korea Exchange

51) Of recent, however, the Supreme Court denied lifting of the corporate veil in a case involving a similar set of facts. In Judgment of Sep. 11, 2008, 2007Da90982 (Supreme Court of Korea), the defendant held de facto control over Company I. Later on, the defendant wound up Company I on the brink of its bankruptcy, while setting up Company 2 that took over both the goodwill and personnel of Company I. The defendant also took control of Company 2. The defendant subsequently dissolved Company 2 and incorporated in its place Company 6 in the name of a third party. Against this backdrop, the Daegu High Court ruled that the defendant's denial of payment obligations vis-à-vis the plaintiff on account of the separate personhood of Company 2 would embody an abuse of corporate personality in violation of the principle of good faith, as well as justice and equity. The Supreme Court, however, overturned the High Court by noting that: i) there had been no substantial mix of assets between Company 2 and the defendant to the point of stripping Company 2 of its separate legal entity. Even when considering all the factors probed by the High Court, the Court could not ascertain that Company 2 had somehow amounted to a private business of the defendant in that the defendant was simply borrowing the corporate form of Company 2 in carrying on legitimate private business; and ii) under the principle of limited liability, there is nothing illicit about winding up a corporation that is no longer a going concern, and subsequently setting up and managing a new corporation via fresh injection of capital in so far as such sequential measures are not aimed at harming creditors. In light of the extent to which the assets of Company 2 and the defendant were commingled, which was far from substantial, the Court was unable to identify any abuse by the defendant of the corporate personality of Company 2 and, as a result, remanded the case back to the High Court.

52) Han-sung Cha, Beopinkyeok buinron [Doctrine of Disregard of the Corporate Entity], STUDY OF Civil Case Laws Vol. XXIV 568, 597 (Bak-young-sa 2002).

53) In Korea, there is a unique way of renting a house called Jeonse, in which a tenant makes a lump-sum deposit on a rental space, instead of paying monthly rents, and gets back the entire deposit when the tenancy comes to an end. Jeonse-kwon (權) refers to a tenant's right to such leasehold machination. See http://en.wikipedia.org/wiki/Real_estate_in_South_Korea (last visited Aug. 31, 2009). 
Bank, a secured creditor with a higher ranking than the plaintiffs, and, in the process, the plaintiffs' respective jeonse-kwon were invalidated. As a result, the plaintiffs could not secure their rental deposits back from Angunsa. In the midst of this imbroglio, the plaintiffs commenced an action at the Western District Office of the Seoul District Court against Angunsa for return of the rental deposits, and Angunsa was ordered to pay them back to the plaintiffs.

In the meanwhile, following the bankruptcy of Angunsa, the defendant company came into existence. Angunsa and the defendant were identical or akin to each other in trade name, commercial emblems, objects of operation, address of the main office, and composition of overseas affiliates. ${ }^{54)}$ Also, the two companies were similar when it came to the makeup of executives and shareholders in that they mainly consisted of close relatives or employees of Yong-Sik An who assumed the dual roles of the controlling shareholderRepresentative Director at Angunsa. ${ }^{55)}$ In terms of the actual management, the defendant held itself out to be synonymous with Angunsa since Yong-Sik An assumed the Representative Directorship at the defendant company. As such, Angunsa and the defendant were treated equal by outsiders, and the defendant won certain projects on that basis. ${ }^{56)}$

\section{2) Judicial rulings of 2002Da66892}

On the issue of veiling piercing, the Supreme Court reasoned as follows in ruling in favor of the plaintiffs. If an existing company has set up a new company that is identical in substance and form to itself for the purpose of eluding legal obligations, such act of incorporation amounts to an abuse of the corporate law system in furtherance of illicit objectives. ${ }^{57)}$ In such context, therefore, allowing a claim asserting the separate legal entity of two putatively distinct companies vis-à-vis the creditors of the existing company cannot be accepted, since such claim vitiates the principle of good faith and trust. ${ }^{58)}$ Thus, a creditor of the existing company may demand the fulfillment of financial obligations against either of the two companies. ${ }^{59)}$

\footnotetext{
54) 2002Da66892, at 2015.

55) Id.

56) Id.

57) Id. at 2014.

58) Id.
} 
In the present case, the defendant company was identical or akin to Angunsa in trade name, commercial emblem, objects of operation, location of the main office, and constitution of overseas affiliates. The vast majority of directors and shareholders of the defendant were either Yong-Sik An's close relatives or his former employees at Angunsa where Yong-Sik An had held the Representative Directorship in his capacity as the controlling shareholder. The defendant held out itself as equal with Angunsa in carrying out marketing and sales activities. In the eyes of outsiders, therefore, the defendant was viewed as the alter ego of Angunsa, and defendant captured projects as such. In addition, Yong-Sik An continued to carry out his roles and responsibilities as the Chairman of the defendant. ${ }^{60)}$ Moreover, faced with a judicial order forcing the defendant to assume the obligations of Angunsa, Yong-Sik An's son and others set up a company named Mutech Korea and won projects related to the defendant. ${ }^{61)}$ Further, on October 20, 1999, Angunsa transferred its interior construction business to the defendant. ${ }^{62}$ In light of these evidentiary elements, the Court found it sufficient to hold that Angunsa had incorporated the defendant, which was substantially identical to Angunsa in corporate form and substance, for the purpose of jettisoning its own financial obligations. ${ }^{63)}$ As such, the Court could not allow the defendant to hide behind Angunsa's separate personhood. Holding otherwise, the Court opined, would not comport with the principle of good faith. ${ }^{64), 65)}$

In this judgment, the Supreme Court imputed liability to the defendant company, which was set up in a way effectively identical to Angunsa in corporate form and substance for the purpose of avoiding away the pecuniary liabilities of Angunsa. It is submitted that this case is factually distinguishable

59) $I d$.

60) Id. at 2015.

61) Id.

62) Id.

63) $I d$.

64) Id.

65) It appears that the Supreme Court affirmed the principle of corporate veil piercing in this case based on the unity of ownership and financial stakes, and presence of illicit purposes as exemplified by evasion of pecuniary obligations. In addition, albeit not explicitly stated, the Court here appears to have applied the enterprise liability doctrine in that, not unlike 87Daka1671, the facts of 2002Da66892 also involved multiple incorporations (namely, Angunsa and defendant company) under common ownership. See supra note 29. 
from other cases in that there was no direct shareholding relationship between the defendant and Angunsa, both of which were controlled by a single shareholder.

Typically, the principle of veil piercing comes handy where a creditor seeks to hold shareholders of a company personally accountable for the company's obligations. Yet, with time, abuse of the corporate entity has taken on a variety of forms, one of which is sequential incorporations of the same business under common ownership. As a matter of principle, there is nothing illicit about winding up a corporation that is no longer a going concern, and subsequently setting up and managing a new corporation via fresh injection of capital in so far as such successive measures are not aimed at harming creditors. In a context involving sequential incorporations, a question nevertheless arises as to whether the successor company may assert the separate legal entity of both its own and of its predecessor against the creditors of the predecessor corporation. It hence becomes increasingly important for courts to set out under what circumstances and specific criteria the successor's assertion can make a viable claim.

Beginning with 2002Da66892, in cases involving sequential incorporations by a common owner, the Court has probed whether the principal possessed an intent to evade legal obligations in deciding whether to pierce the veil or not. Specifically in 2002Da66892, the Court listed an identity of corporate form and substance between the predecessor and successor as the key element for proving the principal's intent. ${ }^{66)}$ The Court in 2006Da24438 ${ }^{67)}$ further refined 2002Da66892 by requiring an appraisal of the totality of pertinent circumstances including the overall state of managerial affairs at the time of the predecessor's dissolution and the payment of arms length dues regarding transfer of assets, if any, from the predecessor to the successor.

In this respect, certain jurists may balk at extending the veil piercing to sequential incorporations since such extension may result in dilution of limited liability. Despite such concern, judicial expansion of the outer

66) For a criticism that the Court's ratio here is unclear and vague, see Young-ae Kwon, Chaemumyeontalmokjeokeuro sullipdwen daechaehwesaeui beopinkyeok buin [Veil Piercing of Alternate Companies Established for Liability Evasion], 8 Com. CASE L. Rev. 1, 14 (Mar. 2005).

67) Judgment of Aug. 21, 2008, 2006Da24438 (Supreme Court of Korea). 
boundaries of veil piercing is welcome and seems warranted in that rapid changes in commercial practice will inevitably diversify ways in which abuse of corporate entity are carried through. As such, courts will need to reckon with this commercial reality by proactively adopting veil piercing, where appropriate, on a case specific basis, in accord with the principles of justice and equity.

\section{Analysis of 2004Da26119}

\section{Basic Facts}

Korea Telecom Philippines Inc. ("KTPI”), a wholly owned subsidiary of defendant in the Philippines, entered into two separate Contracts for Project Management, Supply and Installation of Outside Plant Facilities (collectively "OSP Agreement") with Philippine Telegraph and Telephone Corporation ("PT\&T") on October 11, 1995 and November 12, 1996, respectively, for communication network extension projects near Manila (collectively the "Project"). ${ }^{68)}$ In connection with the Project, KTPI acted as the project manager and subcontracted portions related to the supply of materials, provision of services, and installation of communication lines to certain Korean companies including the plaintiff. ${ }^{69)}$ The plaintiff signed off two agreements with KTPI, one on October 13, 1995 and the other on November 12, 1996 pertaining to communication line installation and supply of raw materials, respectively ("Subject Contracts"). ${ }^{70)}$

Pursuant to the OSP Agreement and Subject Contracts, PT\&T was to pay twenty percent of the total contract price directly to plaintiff. ${ }^{71)}$ As for the remaining portions, PT\&T was obliged to pay KTPI by installed re-payment over seven years with a three year grace period, and KTPI, in turn, was obliged to pay the plaintiff via installed repayment over two years with a

\footnotetext{
68) 2004Da26119, at 1602.

69) $I d$.

70) $I d$.

71) $I d$.
} 
grace period of three years. ${ }^{72)}$

The size of KTPI's capital was approximately KRW 1.6 billion, whereas the total volume of the OSP Agreement amounted to $\$ 87$ million (later increased to $\$ 95$ million through contractual amendments). ${ }^{73)}$ For financing purposes, KTPI signed off a credit agreement with The Chase Manhattan Bank ("CMB") on July 24, 1996 with a credit ceiling capped at \$40 million ("Credit Agreement"). ${ }^{74}$

Prior to the Credit Agreement, defendant entered into a guarantee agreement with $\mathrm{CMB}$ in relation to the financing to be provided under the Credit Agreement (the "Chase Loan") following an affirmative resolution of defendant's management advisory committee. Under the Credit Agreement, KTPI took out the Chase Loan on demand and paid the plaintiff contract monies and interests thereon in accordance with the Subject Contracts. ${ }^{75)}$

In the meanwhile, in the wake of an Asian financial crisis in 1997, PT\&T declared a debt moratorium around June 30, 1998. ${ }^{76)}$ In response, the defendant directed KTPI to minimize withdrawal of what was left of the Chase Loan and consult in advance with the defendant thereby blocking in effect further drawing out by KTPI of the Chase Loan. ${ }^{77)}$ KTPI, in turn, stopped payments to the plaintiff under the Subject Contracts. The plaintiff also halted what remained outstanding of their material supplies to PT\&T. ${ }^{78)}$

On or about October 26, 2000, the plaintiff and KTPI confirmed the balance of account payables under the Subject Contracts at $\$ 20,978,488.23$. Subsequently, on or about March 6, 2001, KTPI paid out to the plaintiff $\$ 1,956,998.44$ in partial fulfillment of said account payables. ${ }^{79)}$ The plaintiff instituted a suit on September 12, 2001 for the purpose of claiming the balance. ${ }^{80)}$
72) Id.
73) Id.
74) Id. at 1603 .
75) Id.
76) $I d$.
77) Id.
78) Id.
79) Id.
80) Id. 


\section{Court Rulings}

\section{1) Judgment of Apr. 30, 2004, 2003Na11891 (Seoul High Court) ${ }^{81)}$}

In general, when a company takes on the appearance of a corporation but such appearance is but a façade, and the company, in essence, amounts to no more than a sole proprietorship of the equity holder behind the corporate veil or to a tool for circumventing contractual obligations, exempting the principal from the liability of what is ostensibly an act of the company, under the pretext of the company's distinct legal persona, would dispel not only the principle of good faith, but justice and equity. ${ }^{82)}$ In such a context, therefore, both the company and the principal alike ought to be rendered answerable to the corporate act in question (in this regard, refer to 97Da21604 $4^{83)}$ ). ${ }^{84}$

In particular, in order for the principle of veil piercing to apply in a parent -subsidiary relationship, the following criteria must be found present: i) a mere fact of the parent company holding sway over the subsidiary by virtue of wholly owning the subsidiary with attendant power to appoint directors and officers by exercise of shareholder rights, will not pass muster. It is necessary that the subsidiary has lost independent volition or existence, with the parent exerting complete control to the point of operating the subsidiary as part of its own business clan; ii) there should be comingling of assets, business operation, and/or external corporate transactions between the parent and the subsidiary; iii) consolidation of accounts ought to be put in place between the two entities in tandem with disregard by the subsidiary of corporate formalities and protocols; iv) the size of the subsidiary's capital must be

81) At the high court level, the plaintiff specifically alleged that: i) KTPI lacked independent payment and overall fiscal abilities; ii) the defendant exerted complete dominion over KTPI by way of shareholders meetings and board of directors meetings, with authority to issue business related directions, plan budgets, pay out salaries and implement human resources policies; iii) the defendant's direction caused KTPI to stop drawing out the Chase Loan; and iv) since KTPI had been dissolved and hence rendered insolvent, absolving the defendant of contractual liabilities under the Subject Contracts on account of KTPI being a separate legal entity, would be at odds with the principle of good faith.

82) 2003Na11891, at 3, Da, (1), (Ga).

83) See supra II. 3.

84) supra note 82. 
conspicuously small for the overall tenor and volume of business it carries on; v) the corporate entity of the subsidiary must have been misused as an instrument to evade liability at the end of the parent. ${ }^{85}$ )

In addition, the high court added the caveat that, as an exception to limited corporate liability, the remedy of veil piercing will be granted only when the corporate personality in question is put to use for illicit objectives, or in violation of public policy, or as an instrument for rationalizing what is otherwise illegal, or to perpetrate fraud or aid and abet a crime, with the aim of stalling or making good such wrongs in line with the principles of equity. ${ }^{86)}$ As such, courts will not lift the corporate veil when: i) the other party in a transaction could distinguish the parent from the subsidiary and was clearly aware of which entity it was dealing with; or ii) such other party was cognizant of the subsidiary being undercapitalized and still proceeded with the transaction without precautionary measures; or iii) there is no clear and convincing proof of illegality in the underlying transaction. ${ }^{87}$

In the case at hand, the Seoul High Court found that: i) there were clear divides in organization, assets, accounting, and details of business flow between the defendant, a domestic Korean corporation, and KTPI, an offshore Philippines corporation; ii) the size of KTPI's capital was approximately KRW 1.6 billion, which might have been a bit small in light of KTPI's obligations under the Subject Contracts. Yet given the fact that KTPI had taken the role of an intermediary between PT\&T and the plaintiff, rather than the ultimate payer, to facilitate the flow of credit, the size of KTPI's capital was not deemed markedly diminutive; iii) based on its full ownership of KTPI, the defendant held strong leverage over KTPI in a broad spectrum of areas including convening of shareholders and board of directors meetings, and matters pertaining to human resources, business-related decisions, and remuneration policy. The directors of KTPI were all on secondment from the defendant, and KPTI underwent thorough advance consultation with the defendant before proceeding with each transaction. In the eyes of the court, such working relationship between the defendant and KTPI was not atypical for an overseas subsidiary, and taking on orders or directives from the sole shareholder, as in

85) Id. at $3, \mathrm{Da},(1),(\mathrm{Na})$.

86) Id. at $3, \mathrm{Da},(1),(\mathrm{Da})$.

87) Id. 
the case of KTPI, was in proper alignment with the quintessence of a limited liability corporation. In the meanwhile, KTPI crafted on its own accord the planning, contract execution and performance for each underlying transaction. KTPI also requested the defendant to guaranty the drawing out of project funds while endorsing a debt restructuring plan following the autonomous resolution of KTPI's own Board of Directors despite the defendant's objection. In light of the foregoing, the court was unable to ascertain complete domination over KPTI by the defendant to the point of divesting KPTI of independent volition or corporate existence; iv) further, as noted previously, at the time of entering into the Subject Contracts, the plaintiff was clearly aware that KTPI was privy to the Subject Contracts, not the plaintiff itself; v) the defendant authorized KTPI to make independent calls on withdrawal of the Chase Loan in consideration of KTPI's own pecuniary resources; vi) above all, the high court was unable to spot elements of unfairness in the Subject Contracts to pierce the corporate veil for any abuse of corporate entity. Nor could the court ascertain that the defendant had put KTPI to use for illicit objectives, or against the public good or as an instrument for justifying what is otherwise prohibited at law, and/or to perpetrate fraud or aid and abet a crime. ${ }^{88)}$ Accordingly, the high court dismissed with prejudice the plaintiff's claim that the defendant's refusal to pay out contract monies by virtue of the distinct legal entity of KTPI would bring the principle of good faith into disrepute. ${ }^{89)}$

\section{2) Supreme Court Decision (2004Da26119)}

At the outset, the Supreme Court noted that it would be natural for certain degrees of labor and financial interplay to be in place between a parent company and its subsidiaries. ${ }^{90)}$ As such, the facts that: i) certain officers or employees of the subsidiary are dually employed by the parent; ii) the parent holds sway over the subsidiary through entire ownership of the subsidiary with appurtenant rights to appoint directors, executives or officers; and iii) in spite of an upward spiral in the overall magnitude of the subsidiary's corporate operation, there was no proportional increase in the subsidiary's

88) Id. at 3, $\mathrm{Da},(2),(\mathrm{Ga})$.

89) Id. at $3, \mathrm{Da},(3)$.

90) 2004Da26119, at 1606 . 
capital, will be, in and of themselves, insufficient to render the parent's assertion of the subsidiary's own legal persona an abuse of corporate personality vis-à-vis creditors of the subsidiary. ${ }^{91)}$ To trigger threshold, the Court will require a showing of the parent company's complete domination over the subsidiary to the point of stripping independent volition or existence with the result that the subsidiary is made part of the parent's corporate clan. ${ }^{92)}$ Specifically, there should be objective indicia of assets, businesses and external transactional activities not being clearly distinguished between the parent and the subsidiary but mixed with each other. Above all, the court should be able to pinpoint the subjective motive or purpose with which the parent company arbitrarily abused the subsidiary's independent legal entity for dodging legal or pecuniary obligations. ${ }^{93)}$

In this regard, the court below noted that: i) at the time of entering into the Subject Contracts, the defendant was a public corporation, and KTPI, a company incorporated under the law of the Philippines, was carrying on telecommunications business in the Philippines subject to periodic external audits; ii) as an overseas subsidiary of the defendant, KTPI was capable of mapping out independent management objectives and corresponding budgets; and iii) in light of the universe of facts mused on by the high court including KTPI's assessment and performance of the Subject Contracts on its own accord and request by KTPI of a guarantee from the defendant in relation to the provision of bank credit, the Supreme Court upheld the Seoul High Court's finding that there were clear divides between KTPI and the defendant in organization, assets, accounting, and business details. ${ }^{94)}$ Also, the Court was unable to ascertain any element of illegality from the defendant's use of KTPI in relation to the Subject Contracts. In the final analysis, the Court upheld the high court holding that the defendant could rightfully assert the separate legal entity of KTPI in denying the defendant's contractual liabilities under the Subject Contracts vis-à-vis the plaintiff. ${ }^{95)}$
91) Id.
92) Id. at 1606-1607.
93) Id. at 1607.
94) Id.
95) Id. at 1607-1608. 


\section{Commentary ${ }^{96)}$}

\section{The criterion of subjective intent/purpose}

As the objective indicia for applying veil piercing in a parent companysubsidiary setting, 2004Da26119 required complete parental control of the subsidiary, coupled with intermingling of assets, business and external corporate activities between the two entities. ${ }^{97)}$ The Court also mandated a showing of the subjective motive or purpose with which the parent had abused the legal entity of the subsidiary for pursuit of illicit objectives such as dodging contractual obligations.

In this regard, the Supreme Court's decision is in line with the jurisprudence on the doctrine of aemulatio vicini or abuse of rights in that both require proof on the element of subjective motive or purpose. ${ }^{98)}$ Under this doctrine, which is codified in Article 2(2) of Min Beop [the Civil Code], ${ }^{99)}$ abuse of rights can be sustained on a showing of, inter alia, conscious exercise by the right holder of what is otherwise a lawful right for the sole purpose of inflicting affliction on a neighbor even in the absence of any lawful gain to be derived from such act.

Also, 2004Da26119 appears to be in line with and influenced by the

96) In respect of 2004Da26119, a commentator noted that since the case involved a plea for lifting the corporate veil of an offshore (i.e. Pilipino) subsidiary of the defendant, a Korean corporation, the Supreme Court should have ascertained the appropriate governing law by applying conflicts of law principles in determining whether to lift the veil of such overseas subsidiary or not, and resolved the case in light of the governing law. Yet the Court erred in failing to consider this governing law issue at all. This observation is with merit, but beyond the scope of this piece. See Kwang-Hyun Suk, Oegukhwesaeui beopinkyeok buin [Piercing the Corporate Veil of an Offshore Corporation], LegAL TIMES, Sep. 8, 2008. For further details in this regard, see Tae-Jin Kim, Beopinkyeok buine kwanhan gukjesabeopjeok geomto [Review of Veil Piercing from a Private International Law Perspective], Presentation before the Korean Society of Private International Law (Aug. 29, 2008).

97) The high court required as the objective criteria such factors as the absence of separate accounting machination between a mother company and her subsidiary, disregard of corporate protocols, undercapitalization of the subsidiary, and misuse of the subsidiary's legal entity.

98) For instance, in Judgment of Feb. 14, 2003, 2002Da62319\&62326 (Supreme Court of Korea), the Court required as prima facie proof of an abuse of right that the right holder exercise its right solely for the subjective purpose of inflicting pain and suffering on another party.

99) Article 2(2) provides: "Rights shall not be abused." 
prevailing theory among Japanese legal academics on the requirements of veil piercing. In Japan, the majority of jurists hold the position that extending the application of veil piercing in an indiscriminate manner will run counter to the maintenance of legal certainty. ${ }^{100)}$ As such, the element of illicit or unjust purpose is usually required before any disregard of corporate entity may be attempted. ${ }^{101)}$

In the meanwhile, the majority of Korean jurists take the view that difficulties in substantiating the parental purpose or motive may dampen the overall efficacy of veil piercing. ${ }^{102)}$ In addition, there may be situations where foisting personal liability on the sole shareholder, despite lack of any mala fide on such person's part, would be consistent with the mandates of justice (for instance, when the subsidiary is all but solvent), hence rendering the criterion of subjective purpose/intent dubious at best.

In particular, the Court in 2004Da26119 refused to read or otherwise infer an illegal or unjust motive of the parent from a pre-determined set of facts. ${ }^{103)}$ This set of facts mostly pertained to the other party to the underlying transaction(s). However, the logical outworking of this decision leaves open the possibility that knowledge or (in)action of such other party may well override or obviate the illicit purpose, if any, of the parent. By way of example, there may be situations where the other party in a transaction proceeded with the transaction without cautionary measures despite her awareness of the subsidiary being undercapitalized compared to the risk intrinsic in the transaction, while, all along, the parent did harbor an illicit motive in its relationship with the subsidiary. In such situation, the other party would be barred from asserting abuse of corporate entity by the parent under a theory of the assumption of risk, not based on a piercing theory involving parental purpose or motive.

100) For a similar view in Korea, see Sang-Hyun Song, Bojeungchaemugeum deung (Seoul Godeungbeopwon 74Na2582 pangyulpyeongseok) [Guarantee Liability, etc, Case Commentary on Judgment of Seoul High Court, 74 Na 2582], Legal Times, 8, May 27, 1974.

101) See Chang-Woo Nam, Hwesa beopinkyeok musieui beopli [Legal Theory of Corporate Veil Piercing] (1995), (unpublished Ph.D. dissertation, Korea University) (on file with Korea University).

102) See Id.; see also Chul-Song Lee, Hwesabeop GANGeui (Lectures on Corporate LaW) 5152, (Bak-young-sa 16th ed. 2009).

103) See supra III. 2. 2). 
Needless to say, lifting the corporate veil should be understood and carved out as an exception to limited liability. However, this normative issue might be more efficiently dealt with by tightening the prerequisites for the "objective indicia" without necessarily importing the murky element of parental motive or intent into the overall conceptual schema.

Even assuming, arguendo, ${ }^{104)}$ the need for parental motive or intent is a valid one, courts will still need to rely on certain fact patterns of recurrence or with general applicability for sorting out such motive or intent. In this regard, it may be a prudent move for the Court to delineate what such factual elements are in an effort to ease the inordinate evidentiary burden on plaintiff in proving the purpose/motive at issue. It is anticipated that the criteria set forth in 2006Da24438 ${ }^{105)}$ will serve as a useful guidepost in ongoing judicial efforts in this respect.

\section{The criteria for disregarding the corporate entity in a parent-subsidiary} corporate group

Corporate law, which provides for the separate personality of a legal person, has been traditionally premised on autonomous corporate management accompanied by individual assumption of liability arising there from. Yet with the advance of capitalism, a sizable number of corporations have set up subsidiaries that operate under their tutelage. These corporate groups often act as a single economic unit and evade liability by tinkering with the legal fiction of corporate entity. As a product of this trend, the likelihood for minority stockholders or creditors of the subsidiary to suffer detriment is ever increasing. This state of affairs, in turn, heightens the need for proactive recourse to veil piercing for these stakeholders' protection.

Apart from the foregoing, albeit varying in degree, a subsidiary is in general under control of the parent with substantial ties in respect of, among others, labor and finance. As such, readily lifting the corporate veil on such nexus alone may well enervate the very backbone of corporate law as encapsulated in limited liability. In case of Korean conglomerates, it is the

104) Means 'for the sake of argument.'

105) See supra note 69. 
norm that the parent exerts dominant control over the subsidiary only in relation to significant matters with day-to-day business largely entrusted to the subsidiary. In this type of business milieu, just because the parent exerts certain degrees of domination should not mean that the corporate veil of the subsidiary is to be readily pierced through. While a circle of legal scholars and commentators espouses the view that when the doctrine of corporate veil piercing is applied to Konzern or a corporate group, it should be within the overall framework of dominance and control without regard to abuse or formalization of the corporate entity, $\left.{ }^{106}\right)$ such view leaves open a loophole that disregarding corporate entity on control alone may lead to abuse of veil piercing since there is invariably a chain of control in any given Konzern.

2004Da26119 took it for granted the presence of ties between the parent and the subsidiary in human resources and finance. As such, the Supreme Court found it insufficient to find an abuse of corporate personality vis-à-vis creditors of the subsidiary, from the pertinent facts of the case evincing some semblance of parental control. This judicial pronouncement is welcome in that it limits the likelihood of lifting the corporate veil for the reason of parental control alone and consequently hampering overall legal certainty.

In the meanwhile, the existence of complete parental control, which the Court required as a quid pro quo to veil piercing, may be ascertained in each case by such objective indicia as comingling of assets, business, and/or external corporate activities, ${ }^{107)}$ and this objective requirement appears reasonable. It is hoped that specifically when these indicia can be found present will flesh out through evolution of jurisprudence in the future.

\section{Conclusion}

$2004 D a 26119$ was a landmark setting out the criteria for veil piercing in a parent company-subsidiary setting. The Court's holding in this case was balanced in that the facts of the case did not warrant lifting the corporate veil

106) Dae-Youn Kim, Jibaejongsokhwesae daehan yeongu (2) - Gyeolhapeseoeui beopinkyeok buinron [Second Study on the Parent-Subsidiary Corporation - Veil Piercing in the Context of Merged Corporations], 44-1 Busan U. L. R. 347, 367(2003).

107) See supra note 87. 
as evidenced by distinct divides between the defendant and its subsidiary KTPI in respect of organization, assets, accounting, and business practices. On the other hand, the aspect of the decision mandating the subjective motive of the parent as a pre-condition for veil piercing is a cause for concern in that such proposition would in effect bring the doctrine of veil piercing to a standstill on account of the evidentiary difficulties it will invariably pose in practice.

Since the Court's decision in 2004Da26119, the number of judicial decisions in Korea probing the prerequisites for veil piercing has been on an incremental increase. ${ }^{108)}$ Even though it may be ardent to systemize such criteria due to their general nature and applicability, the remedy of veil piercing will remain at the active disposal of claimants provided that the judiciary continues to hand down more trailblazing cases supplemented by enriching input from the legal academia.

KeY Words: Corporate Entity, Piercing of Corporate Veil, Principle of Good Faith, Corporate Governance, Corporate Law, Korean Supreme Court

Manuscript received: Oct. 5, 2009; review completed: Dec. 1, 2009; accepted: Dec. 10, 2009.

108) See, e.g., Judgment of Jul. 13, 2006, 2004 Da36130 (Supreme Court) and Judgment of Aug. 21, 2008, 2006 Da24438 (Supreme Court). 